\title{
Analysis of protein composition in Organically and Non-Organically grown Sorghum and Barnyard millet
}

\author{
Arun Kumar $\mathbf{N}^{1}$, Sindhu G. $\mathbf{M}^{\mathbf{2}}$ \\ ${ }^{1}$ PG Student of Botany, JSS college of Arts, Commerce and Science, Mysuru, Karnataka \\ ${ }^{2}$ Assistant Professor, PG Department of Botany, JSS college of Arts, Commerce and Science, Mysuru, Karnataka
}

\begin{abstract}
Millets are used for their rich protein content. These days there are two types of millets that are present in the market one is organic and the other type is non-organically grown millets. In the present work analysis of the difference in protein composition of organic and non-organically grown Sorghum and Barnyard millets. Centrifugation method was used to extract 4 types of proteins (ie., Storage proteins) namely Albumin, Globulin, Prolamins and Glutenin. Spectroscopic method (Microplate method) and SDS Gel Electrophoresis methods were applied to determine the protein composition using advanced application like Color grab 'Software J', Curve fit tools to estimate the proteins. As per the results obtained by our observations there was only four fraction difference between them which is considered as negligible in the protein composition, but in market there is double the price for Organic millets compared to Non-organic millets.
\end{abstract}

\section{INTRODUCTION}

Seed storage proteins comprise a major part of the protein content of the seed and have an important role on the quality of the seed. These storage proteins are important because they determine the total protein content and have an effect on the nutritional quality and functional properties for food processing. There is an increasing concern among the consumers whether to buy the products labeled as "Organic seeds "being sold at up to twice the price of unlabelled or non-organic seeds.

In the present study we have chosen to analyze the quantitative and qualitative parameters of seed proteins in major millet, (Sorghum millet) and minor millet, (Barnyard millet). The quantitative and qualitative changes in seed proteins may be useful for identification of spurious products sold in the market. Based on the literature survey we have framed following objectives for the present study. [1]. Reported results using a desktop scanner to quantify the concentration of a starch-iodine complex using scanned images of solutions in well plates.

Absorbance is commonly measured using instruments such as a spectrophotometer, a UV- visible light spectrometer, or Colorimeter that can quantify absorbance at a single wavelength, however, mobile phone with android operating system can also used to achieve sufficient precision and accuracy for quantification of colored compounds. Implementation of an accessible and inexpensive method for colorimetric analysis was described by [2].

A particularly compelling and recants example is the work of [3]. In which they used a cell phone charge - couples' device to quantify an ovarian cancer biomarker, HE4, in Urine.

\section{MATERIALS AND METHODS}

\section{Microplate method}

The seed samples were ground into fine powder was sequentially extracted $5 \mathrm{ml}$ of solvents following the method of [4]. The seed powder was extracted with $5 \mathrm{ml}$ Distilled water for $1 \mathrm{hr}$ and centrifuged at $6000 \mathrm{rpm}$ for 10 min. The supernatant was saved as Albumins. The remaining residue was extracted with $5.0 \mathrm{ml}$ of $1.5 \mathrm{M}$ Sodium Chloride and the supernatant was saved as Globulins. The residue was extracted with $5 \mathrm{ml}$ of $70 \%$ Ethanol for prolamins and the residue was extracted $5 \mathrm{ml}$ of $0.1 \mathrm{M}$ sodium hydroxide to collect Glutelins.

\section{Protein Estimation:}

Protein estimation is carried out using Bradford reagent methodc, 1976). The procedure was modified for Microplate method by [5].

Micro Plate Protocol:

$50 \mathrm{ul}$ of BSA standard and different extracts of the seeds samples Sorghum and Barnyard millets were mixed with 200 ul of Bradford's reagent. The color values were measured with custom made set up to record the color values in RGB AND CYMK Color spaces by using an android mobile phone. The color values were recorded live in color Grab application [6]. 


\section{International Advanced Research Journal in Science, Engineering and Technology}

Vol. 8, Issue 10, October 2021

\section{DOI: 10.17148/IARJSET.2021.81025}

A Standard graph was constructed using all the color values in the Android mobile phones application curve fit tools. The quantitative parameters of protein content were analysed and represented in the Bar Chart.

Electrophoresis of Total Proteins:

SDS Polyacralamide Gel Electrophoresis (SDS-PAGE) was carried by following method [7]. Separting Gel(15\%):TrisHCL buffer $1.5 \mathrm{M}$ ph $8.82 .5 \mathrm{ml}$ was mixed with $5 \mathrm{ml}$ Acrylamide stock solution,1.3ml Distilled water,100 ul $10 \%$ SDS,10ul TEMED and 100ul 10\% APS made up to $10 \mathrm{ml}$.

1. Stacking Gel (4\%):-0.75 $\mathrm{ml}$ of $0.5 \mathrm{M}$ TrisHC buffer ph 6.8 was mixed with $0.4 \mathrm{ml}$ stock acrylamide solution, $1.8 \mathrm{ml}$ distilled water, $30 \mathrm{ul} 10 \%$ SDS, 5ul TEMED, 10ul, 10\% APS made up to $3 \mathrm{ml}$.

2. Sample buffer:- $7.25 \mathrm{ml}$ distilled water was mixed with $1.25 \mathrm{ml} 0.5 \mathrm{M}$ stacking gel buffer, $0.5 \mathrm{~g}, \mathrm{SDS}, 0.5 \mathrm{ml}$ mercaptanol, and made up to $10 \mathrm{ml}$.

3. Loading buffer:-7.25ml distilled water was mixed with $1.25 \mathrm{ml} 0.5 \mathrm{M}$ stacking gel buffer, $0.5 \mathrm{~g}$ SDS, $1 \mathrm{ml}$ glycerol, $0.5 \mathrm{ml}$ mercaptanol and small crystal of bromo phenol blue and made up to $10 \mathrm{ml}$.

Total Protein Extraction:

$10 \mathrm{mg}$ of defatted seed samples of Sorghum and Barnyard millet was extracted in $500 \mathrm{ul}$ of sample buffer containing $0.125 \mathrm{M}$ TrisHCL buffer ph 6.8 containing $2 \%$ SDS and b- mercaptoethanol. The extract was heated in a boiling water bath for 10 minutes. Equal volume of the extract was mixed with loading buffer $0.125 \mathrm{M}$ TrisHCL buffer ph 6.8 containing $2 \%$ SDS, 5\% b-mercaptoethanol, 20\% glycerol and 0.001\% Bromophenol Blue [8].

$25 \mathrm{ul}$ of the samples was loaded into $5 \%$ stacking gel and allowed to run at 80 Volts until the

Bromophenol dye reached the separating gel. The voltage was increases to 120 Volts the

Bromophenol Blue reached the end of the gel

Staining:

Colloidal CBB G-250 Staining method was followed [9].

Densitometry:

The intensity of protein bands was recorded using 'ImageJ' software and comparative analysis of qualitative differences in the total protein profile of the seed samples of Sorghum and Barnyard millet [10].

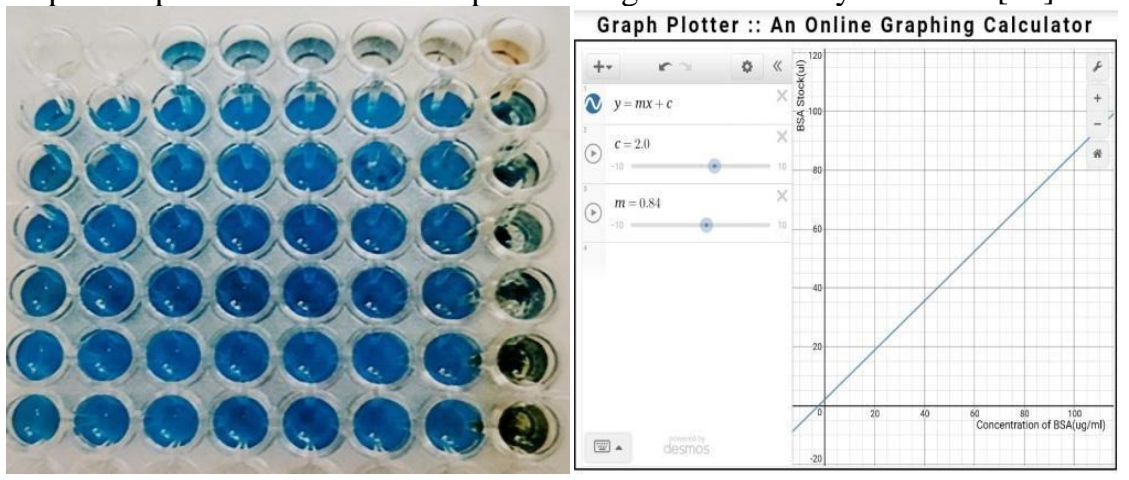

Fig. 1: Microplate analysis Of Barnyard and Sorghum Millets

Fig. 2: Graph from Mobile application curve fit tools

RESULT AND DISCUSSION

Protein Estimation

\begin{tabular}{|l|l|l|l|l|l|l|l|l|l|l|l|}
\hline Millet & \multicolumn{2}{|l|}{ Albumin $(\%)$} & \multicolumn{2}{l|}{ Globulin(\%) } & \multicolumn{2}{l|}{ Prolamine(\%) } & \multicolumn{2}{l|}{ Glutein(\%) } & \multicolumn{2}{l|}{ Total(\%) } \\
\hline & Org & Non- Org & Org & Non- Org & Org & Non- Org & Org & Non- Org & Org & Non- Org \\
\hline Sorghum & 2.2 & 2.25 & 2.15 & 2 & 2.2 & 2.25 & 1.8 & 1.65 & 8.37 & 8.15 \\
\hline $\begin{array}{l}\text { Barnyard } \\
\text { millet }\end{array}$ & 2.2 & 2.25 & 2.12 & 2.2 & 2.22 & 2.25 & 1.67 & 1.65 & 8.21 & 8.15 \\
\hline
\end{tabular}

Four solubility fractions, Albumins, Globulins, Prolamins, Glutelins and Total Proteins were extracted sequentially and quantatively estimated by Bradford's method using Android mobile phone and Micro plate method. The percentage concentration of these fractions is tabulated.

The concentration of Protein fractions and Total Protein content in both Organic and Non-Organic samples show very less variation. The Albumin fraction content was almost equal in quantity with $2.22 \%$ in Organic and $2.25 \%$ in NonOrganic samples. The Globulin content was almost similar with $2.15 \%$ in Organic and 2\% in Non-Organic. The Prolamin content we also similar to that of Albumin and Globulin content with 2.2\% in Organic and 2.25\% in Non- organic. The 


\section{International Advanced Research Journal in Science, Engineering and Technology}

Vol. 8, Issue 10, October 2021

\section{DOI: 10.17148/IARJSET.2021.81025}

Glutelin content was found to be higher in Organic with1.8\% compared to Non- Organic with $1.65 \%$. The Total protein content was also found to show some variation as a higher content with $8.37 \%$ in Organic and $8.15 \%$ in Non-Organic. The concentration of Protein in Barnyard millet, the four protein fractions and Total protein content in both Organic and Non-Organic samples show very less variation. The Albumin fraction content was almost equal in quantity with $2.2 \%$ in Organic and $2.25 \%$ in Non- Organic samples. The

Globulin content was also almost equal in quantity with $2.15 \%$ in Organic and $2 \%$ in NON-Organic samples. The Prolamin content was similar to that of Albumin content with $2.2 \%$ in Organic and $2.25 \%$ in Non-Organic samples. The Glutelin content was found to be almost equaled with $1.67 \%$ in Organic and $1.65 \%$ in Non-Organic. The Total Protein Content Organic with $8.21 \%$ was found to be slightly than in Non-Organic with $8.15 \%$.

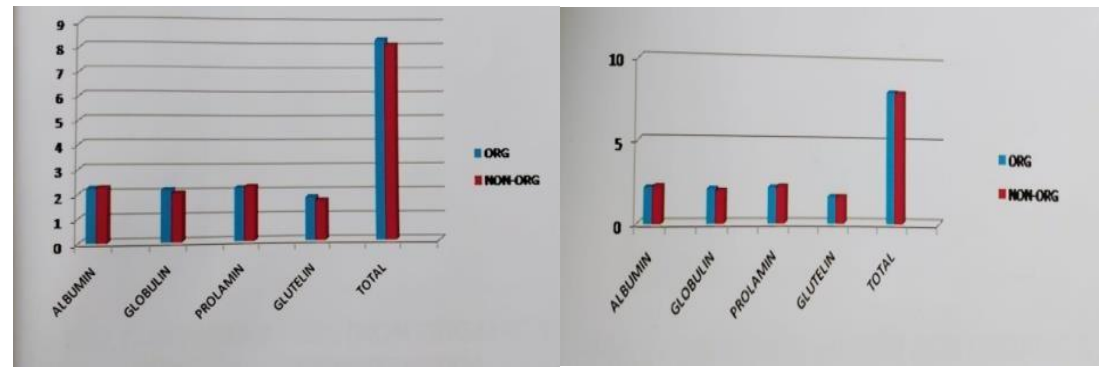

Fig. 3: Graph representing Sorghum Proteins

Fig. 4: Graph representing Barnyard Proteins

\section{Result for Electrophoresis:}

The total Proteins were extracted and separated using SDS-PAGE. $25 \mathrm{ml}$ of sample volume containing equal concentration of Protein were separated in $15 \%$ gel and stained with Ultrasensitive Blue Silver method.

The Sorghum Total Protein gave profile of 9. The highest concentrations of polypeptides were found in range of low molecular weight.

The Barnyard millet Total Protein gave profile of 7. The highest concentrations of polypeptides were found in range of low molecular weight.

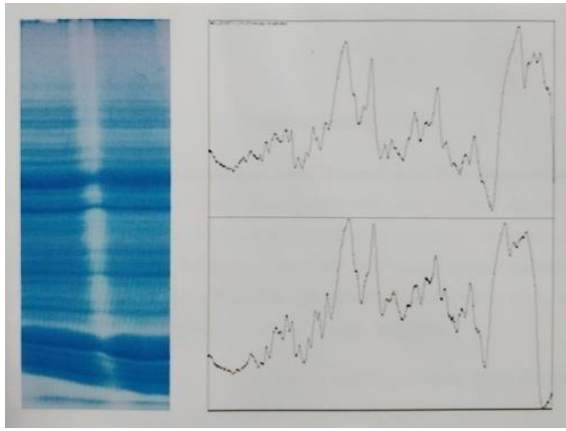

Fig. 5: Sorghum millet gel showing different band.

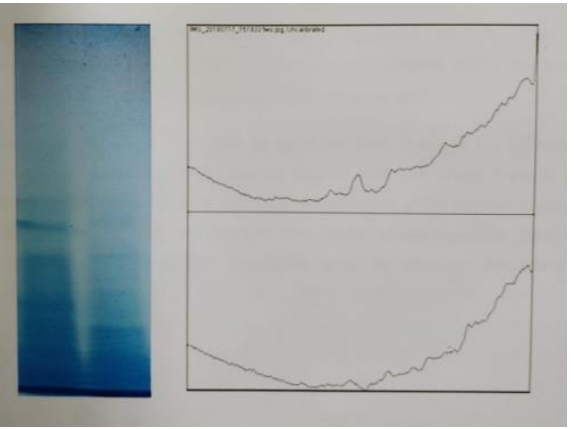

Fig. 6: Barnyard millet gel showing differentband

\section{Discussion :}

The Protein quantity in both organic and Non-Organic samples of Sorghum millet and Barnyard millet show that there is no significant variation with very minute quantitative variation on four fraction and Total Protein. Therefore, the quantitative parameter of Protein content does not justify the eliteness of Organic samples with higher cost compared to the Non- Organic samples.

Selected millets were subjected to different extraction methods to analyze the protein content in the millet samples. Sorghum bicolor (Great millet) reported $12 \%$ of Total Proteins (Nutritive value of Indian foods.

National Institute of nutrition 2007) where our study showed $7.43 \%$ in both organic and Non- Organic millets.

Echinochlo esculenta (Barnyard) millet) reported 10-12\% (Nutritive value of Indian foods.

National Institute of nutrition 2007) where our study showed $7.67 \%$ in both organic and Non- Organic millets.

The main aim of our project is to show that there is no difference between organic and Non-Organic millets and our study reports the same as both Organic and Non-Organic samples show similar analysis and the SDS-PAGE gel images also show almost similar banding patterns and the slight variations may be due to the varietal differences. 


\title{
International Advanced Research Journal in Science, Engineering and Technology
}

\author{
Vol. 8, Issue 10, October 2021
}

\section{DOI: 10.17148/IARJSET.2021.81025}

\section{CONCLUSION}

According to our result there was no difference in the both Organic and Non Organic millet in which both millet showed the same amount of total protein content. So both the millets i.e. one packed as Organic and other packed as Non Organic millets can be used, as both contain same nutritional value.

The protein quantity in both Organic and Non Organic samples of Sorghum millet and Barnyard millet show that there is a slight quantitative variation on four fraction and Total protein. Therefore the quantitative parameter of protein content does not justify the eliteness of Organic samples with higher cost compared to the Non-organic samples.

Also by using microplate method the amount of chemicals used as well as samples can be reduced i.e., in microplate only is used ,so the reagents, samples are used in less quantity which means in less amount. So microplate method is very easy and can be used.

By using colour Grab Android mobile application the colour intensity and the concentration can be calculated very easily for more samples. It is time saving than the colorimeter and spectrophotometer.

The results of this study indicate that digital image analysis can replace a microplate reader for microscale quantitative colorimetric reactions. The microscale nature of these methods leads to a reduction in reagent waste, especially for alkaline or acid regents, and a reduction in cost when the regents are relatively expensive.

\section{REFERENCES}

1. Mathews P. J. "Taphonomy." Ancient starch research, pp. 75-94. 2004.

2. Liebhafsky H. and Winslow E. H. "Photoelectric colorimetry with inexpensive equipment." Journal of Chemical education, pp. 1950.

3. Wang R. Zeeshan ahamed, Faisal nadeem, Mahmood U. and HassanWang." Genome sequence of foxtail millet (Setaria italica) provides insights into grass evolution and biofuel potential." Nature Biotechnology, pp. 549-554. 2014.

4. Osborne T. B. "The proteins of the wheat kernel. Carnegie Institute of Washington, Washington DC. Comparisons of the protein compositions of selected corns and their wild relatives, teosinte and Tripsacum." Agriculture Food Chemistry, pp. 265-270. 1907.

5. Zor T. and Selinger Z. "Linearization of the bradford protein assay increases its sensitivity:theoretical and experimental studies." Anal Biochem, pp. 301-8. 1995.

6. Lowry O. H., Rosebrough N. J. and Randall R. J. "Protein measurement with the Folin phenol reagent.” J. Biol chem, pp. 265-75. 1951.

7. Laemmli U. K. "Cleavage of structural proteins during the assembly of the head of bacteriophage T4." Nature, pp. 680-685. 1970.

8. Ulrich D. J. May W. E. Johnson E. N. "the tolerance of foxtail millet (Setaria latica L. P. Beauv) to combinations of fluroxypyr, clopyralid and MCPA Soils and Crops Workshop." 1996.

9. Candiano G., Bruschi M., Musante L., Santjucci L., Ggiggeri G. M., Carmemolla B., Orecchia P., Zardi L. and Righetti P.G. "Blue silver: A very sensitive colloidalCoomassie G-250 staining for proteome analysis. Electrophoresis.” pp. 1327-1333. 2004.

10. Schneider C. A. Rasband W. S. and Eliceiri K. W. "Potential use of pearl(Pennisetum glaucum L. in Brazil: Food security, processing, health benefits and nutritional products." Food research international, pp. 175-186. 2018. 